\title{
HEMLNINTH AND PARASITIC ARTHROPOD PREVALENCE IN CATFISH CLARIAS BATRACHUS (L.) FROM PONDS IN SAVAR
}

\author{
Hamida Khanum*, Farjana Easmin, Md. Showket Hasan and \\ Rimi Farhana Zaman \\ Department of Zoology, Parasitology branch, University of Dhaka, Dhaka 1000.
}

\begin{abstract}
A total of 115 Clarias batrachus were investigated for parasitic infestation. Out of 1504 parasites recovered from Clarias batrachus, 761 $(50.59 \%)$ were cestodes, 34(2.26\%) trematodes, 58(3.85\%) nematodes and $12(0.79 \%)$ crustaceans ectoparasite. Cestodes showed the highest prevalence $(66.09 \%)$ and the collected parasites were Bovienia serialis, Caryophyllaeus laticeps, Balanotaenia bancroftii, Djombangia penetrans, Orientocreadium batrachoides, Orientocreadium clariae, Procamallanus slomei, Spirocamallanus olsenia and ectoparasite Lernaea cyprinacea. Among the 9 species of parasites, P. slomei (28.69\%) showed the highest prevalence. The moderate prevalence showed by Bovienia serialis and $S$. olsenia (21.74), lowest by O. batrachoides (10.43\%) and Lernaea cyprinacea (10.43). The overall prevalence and mean intensity of parasite infection were $82.61 \%$ and 15.83 respectively. The highest parasitic infestation was found $(88.43 \%)$ in intestine. Cestodes B. serialis, $B$. bancroftii and $D$. penetrans were recovered from stomach and intestine. $P$. slomei were collected from three regions viz. oesophagus, stomach and intestine, while Lernaea cyprinacea from gill. Seasonally the highest prevalence $(90 \%)$ and mean intensity $(24.27 \%)$ was recorded during summer.
\end{abstract}

Key words: Helminth, Arthropods, Parasites, Clarias, Catfish

\section{INTRODUCTION}

Study of parasites in fish is very scant and recent in Bangladesh. These research works are indispensable because of the relationship to human welfare. High parasitic infection often causes fish mortality and ultimately resulting heavy economic loss. In Bangladesh, most of the investigations on fishes have been done in the natural ecosystem. The helminth fauna of both marine and freshwater fishes were investigated by Ahmed and Sanaullah (1977, 1979), Rashid et. al. (1984), Zaman and Khanum (1990), Zaman et al. 1990; and Arther and Ahmed (2002). Furtado and Tan (1973), Leong (1979) and Zaman (1985) investigated the parasite communities of two catfish species viz. Clarias batrachus and C. macrocephalus in the paddy fields of Malaysia. Zaman and Khanum (2012, 2013), Yesmin and Khanum (2013) continued work in this field in Bangladesh as there is good demand and market values for the fish. Khanum and Farhana (2002) and Yesmin and Khanum (2013) worked on the

\footnotetext{
*Corresponding author: hamida_khanum@yahoo.com
} 
histopathological effects in the intestine of indigenous catfish Wallago attu and C. batrachus caused by a Caryophyllid cestode Djombangia penetrans. Fishes with heavy infection of parasites causes deterioration in the food value of fish and may even result in mortality (Zaman and Khanum 2013).

The helminth parasites usually cause the damage in the surrounding of their micro- habitat into the host body. This damage occurs when the parasites pierce the various organs of digestive system for having their food from the host's body; their migration causes disturbances to the host's multiple systems, the cluster of parasite block the channel of fluid in the host body, heavy infection causes deficiency of hosts nutrition, lesions, ulcer and finally the death of the host (Khanum et al. 1996, Khanum and Farhana 2002). The larvae of some species of nematodes migrate extensively in the fish tissues and damage primarily by direct cellular destruction and hemorrhage in the path through fibrous capsules similar to trematodes and cestodes. Mashego and Saayman (1989) worked on digenetic trematodes of Clarias and reported intensive inflammatory responses.

The main objectives of the present study were to determine the helminth and arthropds parasitic fauna, their distribution in fish organ, prevalence in different sexes, months and seasons in Clarias batrachus fish.

\section{MATERIAL AND METHODS}

A total of 115 specimens of Clarias batrachus (L) were collected directly. from three ponds of Savar, Dhaka. The host specimens were collected at random between June' 2010 to May' 2011. The oesophagus, stomach, intestine and rectum were separated and split opened carefully by a longitudinal incision through their entire length and were shaken well with physiological saline solution. Prevalence and intensity of parasites were observed and recorded for each month for months and seasonal studies.

The trematodes were fixed in acetic formal-alcohol (A.F.A) and the cestodes by formalin acetic alcohol (FAA). The helminth and arthropd parasites were preserved in $70 \%$ ethyel alcohol. For cleaning, the parasites were directly put into lactophenol at normal temperature. In case of trematodes, cestodes and nematodes, the cleaned worms were stained and upgraded by alcohol and xylene, mounted as permanent slide. The helminth parasites were identified according to Yamaguti 1985, 1985, 1989) and recent articles.

\section{RESULTS AND DISCUSSION}

A total of 8 species of helminth parasites ( 2 trematodes, 4 cestodes and 2 nematodes) and 1 species of ectoparasite were collected from $C$. batrachus during the study period (Table 1). Prevalence and intensity of different species of parasites varied greatly from one another. The highest prevalence was showed by Procamallanus slomei $(28.69 \%)$ and lowest by Orientocreadium batrachoides (10.43), Bovienia serialis (21.74\%) and Spirocamallanus olsenia $(21.74 \%)$ showed the second highest prevalence (Table 1). 
Table 1. Prevalence and Intensity of different groups of parasites in Clarias batrachus.

\begin{tabular}{llllll}
\hline $\begin{array}{c}\text { Group of } \\
\text { Parasites }\end{array}$ & $\begin{array}{c}\text { No. of fish } \\
\text { examined }\end{array}$ & $\begin{array}{c}\text { No. of fish } \\
\text { infected }\end{array}$ & $\begin{array}{c}\text { Prevalence } \\
\text { (\%) }\end{array}$ & $\begin{array}{c}\text { No. of worm } \\
\text { collected }\end{array}$ & $\begin{array}{c}\text { Mean } \\
\text { intensity }\end{array}$ \\
\hline Trematode & 115 & 34 & 29.57 & 208 & 6.12 \\
Cestode & 115 & 76 & 66.09 & & \\
Nematode & 115 & 58 & 50.43 & 406 & 7 \\
Arthropod & 115 & 12 & 10.43 & 408 & 9 \\
\hline
\end{tabular}

The prevalence of Caryophyllaeus laticeps, Balanotaenia bancroftii, Djombangia penetrans, Orientocreadium clariae were $12.17 \%, 14.78 \%, 17.39 \%$, $19.13 \%$ respectively (Table 2). The intensity also varied greatly. The intensity was highest in $B$. serialis (2.82) and lowest in C. laticeps (0.91) and $L$. cyprinacea $(0.94 \%)$. The intensity of $B$. bancroftii, D. penetrans, $O$. batrachoides, O. clariae, P. slomei and S. olsenia were 1.83, 1.23, 1.53, 1.15, 1.86, and 1.67 respectively.

Table 2. Prevalence and intensity of each species of parasite collected from hosts.

\begin{tabular}{llllll}
\hline $\begin{array}{l}\text { Name of each species } \\
\text { of parasites }\end{array}$ & $\begin{array}{c}\text { No. of host } \\
\text { examined }\end{array}$ & $\begin{array}{c}\text { No. of host } \\
\text { infected }\end{array}$ & $\begin{array}{c}\text { Prevalence } \\
\text { (\%) }\end{array}$ & $\begin{array}{c}\text { No. worm } \\
\text { collected }\end{array}$ & Intensity \\
\hline $\begin{array}{l}\text { Orientocreadium } \\
\text { batrachoides }\end{array}$ & 115 & 12 & 10.43 & 176 & 1.53 \\
$\begin{array}{l}\text { Orientocreadium clariae } \\
\text { Bovienia serialis }\end{array}$ & 115 & 22 & 19.13 & 132 & 1.15 \\
Caryophyllaeus laticeps & 115 & 25 & 21.74 & 324 & 2.82 \\
Balanotaenia bancroftii & 115 & 14 & 12.17 & 105 & 0.91 \\
Djombangia penetrans & 115 & 20 & 14.78 & 211 & 1.83 \\
Procamallanus slomei & 115 & 33 & 17.39 & 142 & 1.23 \\
Spirocamallanus olsenia & 115 & 25 & 28.69 & 214 & 1.86 \\
Lernaea cyprinacea & 115 & 12 & 21.74 & 192 & 1.67 \\
\hline
\end{tabular}


Table 3. Intensity of each species of parasites in male and female hosts separately.

\begin{tabular}{|c|c|c|c|c|c|c|}
\hline \multirow[b]{2}{*}{$\begin{array}{l}\text { Name of } \\
\text { Parasites }\end{array}$} & \multicolumn{3}{|c|}{ Male } & \multicolumn{3}{|c|}{ Female } \\
\hline & $\begin{array}{c}\text { No. of } \\
\text { host } \\
\text { infected }\end{array}$ & $\begin{array}{l}\text { No. of total } \\
\text { worm } \\
\text { collected }\end{array}$ & $\begin{array}{c}\text { Mean } \\
\text { intensity }\end{array}$ & $\begin{array}{c}\text { No. of } \\
\text { host } \\
\text { infected }\end{array}$ & $\begin{array}{l}\text { No. of total } \\
\text { worm } \\
\text { collected }\end{array}$ & $\begin{array}{c}\text { Mean } \\
\text { intensity }\end{array}$ \\
\hline $\begin{array}{l}\text { Orientocreadium } \\
\text { batrachoides }\end{array}$ & 7 & 82 & 11.71 & 5 & 94 & 18.8 \\
\hline $\begin{array}{l}\text { Orientocreadium } \\
\text { clariae }\end{array}$ & 10 & 60 & 6 & 12 & 72 & 6 \\
\hline Bovienia serialis & 9 & 106 & 11.78 & 16 & 218 & 13.62 \\
\hline $\begin{array}{l}\text { Djombangia } \\
\text { penetrans }\end{array}$ & 11 & 68 & 6.18 & 9 & 74 & 8.22 \\
\hline $\begin{array}{l}\text { Caryophyllaeus } \\
\text { laticeps }\end{array}$ & 8 & 71 & 8.87 & 6 & 34 & 5.67 \\
\hline $\begin{array}{l}\text { Balanotaenia } \\
\text { bancroftii }\end{array}$ & 6 & 72 & 12 & 11 & 139 & 12.66 \\
\hline $\begin{array}{l}\text { Procamallanus } \\
\text { slomei }\end{array}$ & 14 & 98 & 7 & 19 & 116 & 6.10 \\
\hline $\begin{array}{l}\text { Spirocamallanus } \\
\text { olsenia }\end{array}$ & 16 & 106 & 6.63 & 9 & 86 & 9.55 \\
\hline $\begin{array}{l}\text { Lernaea } \\
\text { cyprinacea }\end{array}$ & 9 & 66 & 7.33 & 3 & 42 & 14 \\
\hline
\end{tabular}

In $C$. batrachus, it was found that, the intensity of infestation of each species of helminth was different in male and female host. The majority of helminths showed higher intensity in case of female C. batrachus. Only in C. laticeps and $P$. slomei showed higher intensities in case of male fishes than in female fishes. The same intensity is found in B. bancroftii and Afromacroderoides spp. (Table 3).

In the present study, organ distribution, a number of 4 cestodes, 2 trematodes and 2 nematodes and 1 species of ectoparasites were found in different organs of $C$. batrachus (Table 4). B. serialis appeared to have two favoured niches; stomach (20.99\%) and intestine (79.01\%) of C. batrachus. $C$. laticeps showed its abundance only in the intestine. B. bancroftii, $(26.54 \%)$ of the parasite inhibited the stomach and (73.46\%) inhibited the intestine of the host. $D$. penetrans was found to inhibit the stomach $(11.26 \%)$ and intestine $(88.73 \%)$ of the host. O. batrachoides was found to favour the niche of intestine of the host. O. clariae also showed its abundance in the intestine of the host.

The prevalence of parasitic infestation exhibited $P$. slomei was found to in three portion of gut of the host. Majority of this parasite was found to favour the niche of intestine $(87.85 \%)$, Moderate number of parasite was found in the stomach $(9.81 \%)$ and a few number was observed in the oesophagus $(2.34 \%)$. Spirocamallanus olsenia observed in the intestine of $C$. batrachus. In case of male fish, the highest prevalence (100\%) was recorded in the months of June, December, March and May. The prevalence of infestation was equal in the month of July, October and January $(75 \%)$. The prevalence was comparatively higher in the month of February (85.7\%) (Table 5). 
On the other hand, in case of female, the highest prevalence (100\%) was obtained in June July, September, December, February, March. It was comparatively higher in April (88.84\%), November (75\%) and October (71.43\%). In the month of January 2007 the prevalence was 66.66\% (Table 5).

Table 4. Organal distribution of different parasites in C. batrachus.

\begin{tabular}{lcllll}
\hline Name of Parasites & Gill & Oesophagus & Stomach & Intestine & Total \\
\hline $\begin{array}{l}\text { Orientocreadium } \\
\text { batrachoides }\end{array}$ & 0 & 0 & 0 & $176(100 \%)$ & 176 \\
Orientocreadium clariae & 0 & 0 & 0 & $132(100 \%)$ & 132 \\
Bovienia serialis & 0 & 0 & $68(20.98 \%)$ & $256(78.76 \%)$ & 324 \\
Caryophyllaeus laticeps & 0 & 0 & 0 & $105(100 \%)$ & 105 \\
Balanotaenia bancroftii & 0 & 0 & $56(26.54 \%)$ & $155(73.56 \%)$ & 211 \\
Djombangia penetrans & 0 & 0 & $16(11.27 \%)$ & $126(88.73 \%)$ & 142 \\
Procamallanus slomei & 0 & $5(2.33 \%)$ & $21(9.81 \%)$ & $188(87.85 \%)$ & 214 \\
Spirocamallanus olsenia & 0 & 0 & 0 & $192(100 \%)$ & 192 \\
Lernaea cyprinacea & $12(11.11 \%)$ & 0 & 0 & 0 & 108 \\
\hline
\end{tabular}

Table 5. Monthly prevalence of parasites in male and female Clarias batrachus.

\begin{tabular}{lllllll}
\hline \multicolumn{1}{c}{ Months } & \multicolumn{2}{c}{ Male } & \multicolumn{3}{c}{ Female } \\
\cline { 2 - 7 } & $\begin{array}{c}\text { No. of } \\
\text { total fish } \\
\text { examined }\end{array}$ & $\begin{array}{c}\text { No. of } \\
\text { total fish } \\
\text { infected }\end{array}$ & $\begin{array}{c}\text { Prevalence } \\
\text { (\%) }\end{array}$ & $\begin{array}{c}\text { No. of } \\
\text { total fish } \\
\text { examined }\end{array}$ & $\begin{array}{c}\text { No. of } \\
\text { total fish } \\
\text { infected }\end{array}$ & $\begin{array}{c}\text { Prevalence } \\
\text { (\%) }\end{array}$ \\
\hline June'2011 & 4 & 4 & 100 & 6 & 6 & 100 \\
July & 8 & 6 & 75 & 5 & 5 & 100 \\
August & 6 & 4 & 66.66 & 2 & 0 & 0 \\
September & 4 & 2 & 50 & 8 & 8 & 100 \\
October & 8 & 6 & 75 & 7 & 5 & 71.43 \\
November & 6 & 4 & 66.66 & 4 & 3 & 75 \\
December & 1 & 1 & 100 & 7 & 7 & 100 \\
January'2012 & 4 & 3 & 75 & 3 & 2 & 66.66 \\
February & 7 & 6 & 85.71 & 5 & 5 & 100 \\
March & 3 & 3 & 100 & 2 & 2 & 100 \\
April & 1 & 0 & 0 & 9 & 8 & 88.89 \\
May & 4 & 4 & 100 & 1 & 1 & 100 \\
Total & 56 & 43 & 76.79 & 59 & 52 & 88.14 \\
\hline
\end{tabular}


Table 6. Seasonal variation in the intensity of each species of parasites collected from $C$. batrachus.

\begin{tabular}{|c|c|c|c|c|c|c|c|c|c|}
\hline \multirow[b]{2}{*}{$\begin{array}{l}\text { Name of the } \\
\text { parasites } \\
\text { collected }\end{array}$} & \multicolumn{3}{|c|}{ Rainy } & \multicolumn{3}{|c|}{ Winter } & \multicolumn{3}{|c|}{ Summer } \\
\hline & $\begin{array}{c}\text { No of host } \\
\text { infected }\end{array}$ & $\begin{array}{l}\text { No. of } \\
\text { parasites } \\
\text { collected }\end{array}$ & $\begin{array}{c}\text { Mean } \\
\text { intensit } \\
y\end{array}$ & $\begin{array}{c}\text { No of } \\
\text { host } \\
\text { infected }\end{array}$ & $\begin{array}{c}\text { No. of } \\
\text { parasites } \\
\text { collected }\end{array}$ & $\begin{array}{c}\text { Mean } \\
\text { intensity }\end{array}$ & $\begin{array}{c}\text { No of } \\
\text { host } \\
\text { infected }\end{array}$ & $\begin{array}{c}\text { No. of } \\
\text { parasit } \\
\text { es } \\
\text { collect } \\
\text { ed }\end{array}$ & $\begin{array}{c}\text { Mean } \\
\text { intens } \\
\text { ity }\end{array}$ \\
\hline $\begin{array}{l}\text { Orientocreadium } \\
\text { batrachoides }\end{array}$ & 9 & 138 & 15.33 & 2 & 55 & 27.5 & 1 & 9 & 9 \\
\hline $\begin{array}{l}\text { Orientocreadium } \\
\text { clariae }\end{array}$ & 14 & 93 & 6.64 & 4 & 38 & 9.5 & 4 & 11 & 2.75 \\
\hline Bovienia serialis & 12 & 165 & 13.75 & 9 & 125 & 13.89 & 4 & 34 & 8.5 \\
\hline $\begin{array}{l}\text { Caryophyllaeus } \\
\text { laticeps }\end{array}$ & 9 & 72 & 8 & 2 & 14 & 7 & 3 & 19 & 6.33 \\
\hline $\begin{array}{l}\text { Balanotaenia } \\
\text { bancroftii }\end{array}$ & 12 & 142 & 11.83 & 4 & 60 & 15 & 1 & 9 & 9 \\
\hline $\begin{array}{l}\text { Djombangia } \\
\text { penetrans }\end{array}$ & 11 & 90 & 8.18 & 5 & 36 & 7.2 & 4 & 16 & 4 \\
\hline $\begin{array}{l}\text { Procamallanus } \\
\text { slomei }\end{array}$ & 24 & 179 & 7.46 & 5 & 27 & 5.4 & 4 & 8 & 2 \\
\hline $\begin{array}{l}\text { Spirocamallanus } \\
\text { olsenia }\end{array}$ & 18 & 131 & 7.28 & 4 & 36 & 9 & 3 & 25 & 8.33 \\
\hline $\begin{array}{l}\text { Lernaea } \\
\text { cyprinacea }\end{array}$ & 9 & 81 & 9 & 2 & 19 & 9.5 & 1 & 8 & 8 \\
\hline
\end{tabular}

During the present work, it was observed that in $C$. batrachus the population of parasites were more abundant in summer season which may be due to the fact that summer and rainy seasons are spawning time of fish and gravid females are more susceptible to infection. During this period, suspected intermediate host of cestodes and trematodes are also abundant. In winter, the parasite population were rare, because after spawning period naturally female may get rid of the worms or heavily infected fish may die before winter.

In the present observation, total four groups of parasites were recovered from C. batrachus namely trematoda, cestoda, nematode and a crustacean arthropod. Larnaea cyprinacea was recorded by Zaman (1985) from the gill of C. batrachus and studied on different aspects of Nemato-parasites in the cat fishes $H$. fossilis and $C$. batrachus in Bangladesh. It was observed from the present study that a large proportion of the parasites recoverd (mainly cestodes) in immature form (Wabuke and Bunoti 1980). Only a small proportion of the parasites were found matured. It would appear that maturation of the parasites in the catfish might be controlled by density dependent factor. This phenomenon has been observed in many parasites such as Tansvrersotrema patialense (Leong 1975) and Acanthocephalas salmonis (Leong 1979 and Mackenzie 1972). Cayophyllaeus laticeps, Orientocreadium batrachoides O. clariae, Spirocamallanus olsenia 
appear to be restricted to a specific habitat in the intestine. This restriction may be due to the fact that the intestinal region may be more soften as compared to other regions of the gut (Khalil 1961, 1972). Satpute and Agarwal (1974) worked on seasonal variation of prevalence of cestodes in Clarias batrachus.

In the present study, cestodes showed highest prevalence and ectoparasitic crustacean arthropod showed lowest prevalence in C. batrachus. In the present study, the female host fishes were observed to be more infected than male. Similar reports were also observed by Rashid et. al. (1984), they concluded that this might be due to lower physiological resistance of female rather than ecological conditions.

Intensity of parasites in C. batrachus were higher in female than male. This result support the view of Chubb (1982). In the present study. Most of the cestodes, the two trematode and one nematode showed their abundance in the intestine rather than stomach, which also agree with the Mackiewcz (1972). It was observed that the intestine was found to favour in large number of parasites than the other parts of the gut. The present result showed that Bovienia serialis, Cayophyllaeus laticeps, Balanotaenia bancroftii, and Spirocamallanus olsenia inhibit both the stomach and intestine. Only, Procamallanus slomei showed its occurrence in oesophagus, stomach and intestine. It is thought that due to easy availability of nutrient substance in the intestine, the parasites favoured mostly this niche. The fish parasites alike to other vertebrates, subsists either on the digested contents or the tissue of the intestine of the hosts (Furtado and Tan 1973).

\section{CONCLUSION}

For the parasitic infestation, multiple changes occurred in the liver, one of them is vacuole formation, causes spongy appearance where fluid accumulated thus the surrounding cells faces more pressure and the normal liver function hampered also the hosts immunity decreased. Moderate numbers of metacercariae caused inflammatory response, while, host reaction to an extremely heavy infection were much more complex, and included gross displacement of tissue, inflammatory responses, rupture of abdomen.

\section{LITERATURE CITED}

AHMED, A.T.A. and SANAULLAH, M. 1977. Observation on the incidence and intensity of some helminths in different length groups of Heteropneustes fossilis (Bloch) and C batrachus (L). Dhaka Univ. Stud. (B), 25 (2): 91-98.

AHMED, A.T.A. and SANAULLAH, M. 1979, Pathological observations in the intestinal lesions induced by caryophyllid cestodes in C batrachus (L.) Siluriformes (Clariidae). Fish path., (Japan) 14 (1): 1-7.

AHMED, T., KHANUM, H. and ZAMAN, RF. 2013. Endoparasitic Helminth infestation in Glossogobius giuris (Hamilton-Buchanan, 1822) J Natural History. 8(4): 27-34.

ARTHER, J.R and AHMED, A.T.A. 2002, Checklist of parasites of Bangladesh. FAO Fisheries technical paper, No. 369/1. PP 77.

CHUBB, J.C. 1982. Seasonal occurrence of helminths in freshwater fishes. Part IV. Adult Cestoda, Nematoda and Acanthocephala. Adv. Parasitol. 20: 1-193. 
FURTADO, J.1. and TAN, K.L. 1973. Incidence of some helminths parasites in the Malaysian cat fish, Clarias batrachus (L), Verh. Internat, Limnol. 18: 1674-1685.

KHALIL, L, F. 1961. On a new Trematode Orlentocreadium LaJerl sp. Nov., Rom a fresh water fish Clarias Lazera, in the Sudam. J. Helminth. 35 (3/4): 259-262.

KHALIL, L.F. 1972. Study on AfroMacroderoides lazerae gen. et sp. nov. (Allocreadidae: Wallininae), a new Digenean from the African fresh water fish C. lazera. J. Helminthology 46 (4): 341-344.

KHANUM, H., FARHANA, R. 2002. Histopathological effects of a trematode Isoparorchis hypselobagri (Billet) in Wallago Attu Bloch and Schneider, Bangladesh J. Zool. 30(1): 65-69, 2002.

KHANUM, H., Zaman. Z. and Ahmed, ATA. 1996. Endoparasite community of two species of genus Ompok Lacepede. Journal of Bengal Natural History Society. New Series, 15(2): 32-36.

LEONG, T.S. 1979. Parasites of fish in Malaysia. A Review. Malaysian Agricultural Jour. 52 (1):29-38.

MACKIEWICZ, J.S. 1972. Two new species of Caryophyllid tape worms from catostomid fishes in Tennessee. J. Parasit. 58 (6): 1075-1081

MASHEGO, S.N. and SAAYMAN, J.E. 1989. Digenetic trematodes and cestodes of Clarias garepinus (Burchell, 1822) in Lebowa, South Africa, with taxonomic notes. South African J. Wildlife-Research. 19 (1):17-20.

RASHID, M., MAMUNUR, HAQUE, AMINUL A.K.M. AND CHANDRA, K.J. 1984. Effect on season, sex and size of Clarias batrachus on the population of Orientocreadium batrachoides in Mymensingh. Bangladesh J. Fish. 7 (1-2): 21-25.

SATPUTE, L. R. and AGARWAL, S. M. 1974. Seasonal infection of Clarias batrachus (L.) Lytocestus indicus Moghe and parasitic effects on its haematology and histopathology. Indian J. Exp. Biol. 12: 584-586.

WABUKE, M. A. N. and BUNOTI. 1980. The prevalence and pathology of the cestode Polyonchobothrium clarias (Woodland, 1925) in the teleost, Clarias mossambicus (Peters). Jour. Fish Disease, 3: 223-230.

YAMAGUTI, S. 1985. Systema, Helminthum. The Digenetic Trematodes of Vertebrates, V1, Part I and I1. International Books and Periodicals Supply Service. :171-172.

YAMAGUTI, S. 1989. Systema Helminthum. The Cestodes of Vertebrates. Voll-11 (I \& 11) Jhon Wiley and Sons. PP-860.

YAMAGUTI, S. 1985. Systema Halminthum. The Nematodes of vertebrates, V-111 (I \& 1): 24.

YESMIN, S. and KHANUM, H. 2013. Histopathological affects due to helminth infestation in Clarias batrachus (Linnaeus) and Clarias gariepinus Burchell. 23rd National Congress of Parasitology. Deptt. Of Zoology, Kalyani University, Kalyani, W.B. p. 309- 315.

ZAMAN, Z., LEONG, T.S. and KHANUM, H. 1986. Effects of lengths (=age) of Clarias on abundance of parasites. Bang. J. Zool. 14: 171-177.

ZAMAN, Z. and SENG, L. T. 1986. Histopathology of the intestine caused by a Caryophyllid cestode, Djombangia penetrans, Bovien, 1926 in catfish Clarias batrachus and Clarias macrocephalus. Tropical Biomedicine 3: 157-160.

ZAMAN, Z. AND KHANUM, H. 1990. The lernaeid copepod parasites: Lernea cyprinicea Linn. in Clarias batraus (L.). The Bangladesh J. Sci. Res. 8 (2): 165-172. 
ZAMAN, Z. and KHANUM, H.A. 1992. Parasites of Catfish. Genus Clarias (Bloch). Deptt. of Zool. Univ. of Dhaka. pp. 63

ZAMAN, Z. 1985. Parasite Fauna of Paddy Field. Catfish (Genus-Clarias) from Kedah and Perak. Peninsular Malaysia. Ph. D. Thesis, Univ. Sains, Malaysia. PP- 288

ZAMAN, Z., LEONG, T.S. and KHANUM H.A 1986. Effects of Lengths (age) of Clarias on abundance of parasites. Bangladesh J. Zool. 14: 171-177.

ZAMAN, R. and KHANUM, H. 2012. Helminth parasites in Mystus aor and Mystus bleekeri. Journal of Natural History (India). 8(2): 65-75.International.

ZAMAN, R.F. and KHANUM, H. 2013. Helminth parasites of Mystus aor (Hamilton) and Mystus bleekeri (Day) in Bangladesh . J. Natural History. 8(2): 65-75

ZAMAN, R.F. and KHANUM, H. 2013. Proximate analysis of Mystus aor (Hamilton) and Mystus bleekeri (day) in relation to parasitic infestation. 23rd National Congress of Parasitology. Deptt. Of Zoology, Kalyani University, Kalyani, W.B. p. 69-78.

(Manuscript received on 1 September, 2015; revised on 6 December 2015) 